\title{
The Kamativi pegmatite: an opportunity for economic development in Zimbabwe?
}

\author{
Richard A Shaw ${ }^{1}$, Kathryn M Goodenough ${ }^{2}$, Eimear A Deady ${ }^{2}$ \& Paul Nex ${ }^{3}$ \\ ${ }^{1}$ British Geological Survey, Keyworth, Nottingham, UK, rashaw@bgs.ac.uk \\ ${ }^{2}$ British Geological Survey, Edinburgh, UK \\ ${ }^{3}$ University of the Witwatersrand, South Africa
}

Keywords: Kamativi, Zimbabwe, ASM, tin, lithium

\section{Introduction}

The last few years have seen a dramatic change in global attitudes to electric vehicles (EVs) with many countries and car manufacturers pledging to switch entirely to EVs before 2040. The expected growth in EVs will lead to a rapid increase in demand for raw materials such as lithium, which is essential for batteries in EVs and domestic energy storage systems. Lithium-Caesium-Tantalum (LCT) pegmatites are an important source of lithium, currently accounting for about $40 \%$ of global supply.

Zimbabwe is currently the world's fifth largest lithium producer, after Chile, Argentina, Australia and China, and has substantial lithium resources (USGS, 2018). All lithium in Zimbabwe currently comes from pegmatites, with production chiefly from the Bikita Pegmatite. Other pegmatite prospects of interest include Arcadia (Prospect Resources), Zulu (Premier African Minerals) and Kamativi (CAT Strategic Metals Inc. and Zimbabwe Mining Development Corporation).

The Kamativi pegmatite is a large LCT-type pegmatite located in northern Zimbabwe. The pegmatite was worked on a commercial scale between 1936 and 1994, producing about 37,000 tonnes of tin and 3,000 tonnes of tantalite during its lifetime (Cronwright \& Derbyshire, 2018). However, lithium was never extracted from the pegmatite. The tailings at Kamativi are being evaluated by CAT Strategic Metals Inc. for their lithium potential. Current estimates indicate a resource of about 26 million tonnes at about 0.6 wt. \% $\mathrm{Li}_{2} \mathrm{O}$ (CAT Strategic Metals Inc., 2019).

The Kamativi pegmatite is one of several large LCT-type pegmatites in Zimbabwe; however, very little is known about its formation, or its relationship to the country rocks in which it is found. This lack of geological understanding could seriously hamper future development (M. Pittuck, pers. comm., 2018). By using Kamativi as a case study we aim to develop a genetic model that helps us understand the formation of lithium-bearing pegmatites in Zimbabwe. This will improve exploration models and thus contribute to Zimbabwe's economic development.

\section{Regional geological setting and geochronology}

The geology of Zimbabwe is dominated by Archaean gneisses of the Zimbabwe craton. The northwestern margin of the craton is marked by the Palaeoproterozoic Magondi Mobile Belt, which lies unconformably on the Archaean gneisses (Master et al., 2010). The Kamativi pegmatite is located in the Dett-Kamativi inlier, which is a broadly northeast-southwest trending belt of Palaeoproterozoic metamorphic rocks assigned to the Magondi Supergroup, surrounded by younger Mesozoic Karoo sedimentary rocks and Cenozoic aeolian sands of the Kalahari Group. The rocks of the inlier consist of granodioritic orthogneisses, granites and a metasedimentary sequence that can be divided into the Malaputese, Inyantue, Kamativi and Tshontanda formations (Master et al. 2010). The orthogneisses have been dated at c. $2700 \mathrm{Ma}$ and the granites at 2060-2020 Ma (Glynn \& Master, 2017). The metasedimentary rocks were deformed and metamorphosed to amphibolite and granulite facies during the Magondi Orogeny at around 2060-1960 Ma (Master et al., 2010; Glynn \& Master, 2017). Pegmatites in the Dett-Kamativi inlier are almost entirely confined to the Kamativi Formation, which is dominated by pelitic schists. Tinmineralised pegmatites in the inlier have been dated by $\mathrm{Pb}-\mathrm{Pb}$ methods in columbite, giving ages of around 1030-930 Ma (Melcher et al., 2015; Glynn \& Master, 2017). Ar-Ar dating of biotite and muscovite from 
metasedimentary rocks in the inlier suggests a thermal peak at around the same time (1050-950 Ma); however, this thermal peak is not linked to any specific deformation event that has previously been described in the Dete-Kamativi inlier (Glynn \& Master, 2017).

\section{Pegmatites at Kamativi}

There are two main types of pegmatite in the Kamativi district: (1) vertical, or steeply-dipping tourmaline pegmatites that strike parallel to the steep foliation in the metasedimentary host rocks; and (2) large (up to $30 \mathrm{~m}$ thick), poorly-zoned, flat-lying mineralised pegmatites and associated aplites that clearly cross-cut the fabrics in the host rocks. Cross-cutting relationships are clear and the flat-lying Type 2 pegmatites are demonstrably younger than the steep, Type 1 pegmatites.

Type 1 pegmatites largely comprise quartz, muscovite mica, alkali feldspar and tourmaline, whereas Type 2 (mineralised) pegmatites contain quartz, muscovite mica, albite, and spodumene as the main lithium-bearing mineral. They also contain cassiterite, columbite-tantalite group minerals (CGM), blue tourmaline and beryl. Type 2 pegmatites are also characterised by a late-stage albite + quartz assemblage that is typically associated with cassiterite. Another common feature of Type 2 pegmatites is the pervasive replacement of spodumene by fine-grained mica. The margins of Type 2 pegmatites are typically poorly mineralised, containing little in the way of cassiterite or lithium minerals; however, mica and black (schorl) tourmaline are much more abundant at the pegmatite margins.

Approximately $40 \mathrm{~km}$ west of Kamativi, at Kapami, thin (up to $50 \mathrm{~cm}$ thick), flat-lying, pegmatites are found cross-cutting the foliation in the local granite. The pegmatites here are very similar to Type 2 pegmatites seen at Kamativi and comprise quartz, muscovite mica, albite, but only minor amounts of spodumene. They also contain blue tourmaline, cassiterite and CGM. The late-stage albite + quartz assemblage seen elsewhere is also present in pegmatites at Kapami, as is the alteration of spodumene to mica. However, the alteration of spodumene in the Kapami pegmatites appears to be less pervasive than in the pegmatites at Kamativi.

At Kalinda, pegmatites up to $5 \mathrm{~m}$ thick are variably mineralised, containing some cassiterite and CGM, but little or no lithium-bearing minerals. The pegmatites here are relatively steeply-dipping, but can be highly irregular with offshoots that cross-cut the country foliation. The late-stage albite + quartz assemblage appears to be absent in the Kalinda pegmatites.

According to Selway et al. (2005) the composition of muscovite mica can be used to assess the economic potential of a rare-metal pegmatite. Specifically, muscovite mica with a $\mathrm{K} / \mathrm{Rb}$ ratio $<20$ and a $\mathrm{Cs}$ content in excess of $500 \mathrm{ppm}$ are of particular interest. Laser ablation ICP-MS analysis of hand-picked mica from pegmatites at Kamativi, Kalinda, and Kapami confirm that the main Kamativi pegmatite and the pegmatites at Kapami are most prospective for Li-Cs-Ta mineralisation. Whereas muscovite from a Type 1 pegmatite at Kamativi, and from the pegmatites at Kalinda, clearly show these to have little mineralisation potential.

The genesis of the two suites of pegmatites is poorly understood. The age of the Type 1 pegmatites is not known; the Type 2 pegmatites are dated at c. 1030 Ma (Glynn et al., 2017). Outcrops in the Gwai River Gorge, close to the Kamativi Mine, clearly indicate a period of intense deformation (potentially in localized shear zones) that post-dates emplacement of the Type 1 pegmatites and pre-dates Type 2 . The Type 2 pegmatites are of a similar age to the tin granites and pegmatites of the Kibaran Belt in Central Africa (Melcher et al., 2015).

\section{Summary}

Type 1 (barren) pegmatites in the Dett-Kamativi inlier represent an early stage of pegmatite formation that is most likely related to the exposed granitoids. However, there is little evidence to suggest that Type 2 (mineralised) pegmatites and aplites are granite-related. Therefore we aim to investigate whether or not Type 2 pegmatites formed by localised anatexis of rocks in the Dett-Kamativi inlier, or whether they formed from a fluid-rich magma generated during the Kibaran Orogeny.

Zimbabwe has excellent mineral resources and has the potential to be a major producer of lithium, tantalum and tin from pegmatites, which could make a major contribution to the country's economy. 
Zimbabwe struggles to bring in the foreign direct investment needed to mine these resources (Mutandwa $\&$ Genc, 2018). Reasons for this are many and varied, and government mineral policy plays an important part. However, there is little doubt that the lack of understanding of the geology and geometallurgy of Zimbabwe's pegmatites hampers both exploration and development of mines. Therefore producing improved exploration models for lithium-bearing pegmatites in Zimbabwe is crucial for the country's future economic development.

\section{Acknowledgments}

The work described here draws on research funded by NERC through the Geoscience for Sustainable Futures ODA programme at BGS. The Zimbabwe Mining Development Corporation (ZMDC), Chimata

Gold Corp (now CAT Strategic Metals Inc.), the Mining Promotions Corporation (MPC) and Premier African Minerals are all thanked for their kind support.

\section{References}

CAT Strategic Metals Inc. (2019): Investor presentation: an emerging lithium producer. Accessed April 2019 at: http://web.catstrategic.com/wp-content/uploads/2019/02/CAT-Strategic-Metals-V3.pdf

Cronwright, M. S. \& J. Derbyshire (2018): NI 43-101 Technical Report: Chimata Gold Corporation Kamativi Lithium Tailings Project, Matabeleland North Province, Zimbabwe: 156.

Glynn, S. M., Master, S., Wiedenbeck, M., Davis, D.W., Kramers, J. D., Belyanin, G. A., Frei, D. and Oberthür, T. (2017): The Proterozoic Choma-Kalomo Block, SE Zambia: Exotic terrane or a reworked segment of the Zimbabwe Craton? Precambrian Research 298, 421-438.

Master, S., Bekker, A. and Hofmann, A. (2010): A review of the stratigraphy and geological setting of the Palaeoproterozoic Magondi Supergroup, Zimbabwe - Type locality for the Lomagundi carbon isotope excursion. Precambrian Research 182, 254-273.

Melcher, F., Graupner, T., Gäbler, H. E., Sitnikova, M., Henjes-Kunst, F., Oberthür, T., Gerdes, A. and Dewaele, S. (2015): Tantalum-(niobium-tin) mineralisation in African pegmatites and rare metal granites: Constraints from $\mathrm{Ta}-\mathrm{Nb}$ oxide mineralogy, geochemistry and $\mathrm{U}-\mathrm{Pb}$ geochronology. Ore Geology Reviews 64, 667-719.

Mutandwa, B. and Genc, B. (2018): Leveraging Zimbabwe's mineral endowment for economic transformation and human development. Resources Policy 58, 230-239.

Selway, J. B., Breaks, F. W. and Tindle, A. G. (2005): A Review of Rare-Element (Li-Cs-Ta) Pegmatite Exploration Techniques for the Superior Province, Canada, and Large Worldwide Tantalum Deposits. Exploration and Mining Geology 14, 1-30.

USGS (2018). Lithium Mineral Commodity Summary. 